\title{
THE LOMCE AS A DEAD END
}

\section{LA LOMCE, UN CALLEJÓN SIN SALIDA}

\author{
Juan Carlos Álvarez López, Daniel Burgos Silva y Tamara Casas Rodríguez. \\ Universidad de Granada
} Artículo dirigido por: Katia Caballero. Departamento de Didáctica y Organización Escolar. Universidad de
Granada

Fecha de recepción: 31 de enero de 2014.

Fecha de revisión: 19 de marzo de 2014.

Fecha de aceptación: 11 de abril de 2014.

\begin{abstract}
The article analyses the new Education Law in Spain, named LOMCE. It is focused on the budget cuts that LOMCE proposes, taking into consideration the consequences this new law will have on teachers, students and the society as a whole. The article does not miss the current economic weakness of our country and tries to show how these budgetary aspects affect education. It also reflects the possibilities that these new proposals will offer to citizens by establishing a comparison between our educational system and one whose success is proved, the Finnish one.
\end{abstract}

KEY WORDS: Rights to education; Education policy; Free access to education

\section{INTRODUCTION}

The educational reforms obey a policy of austerity from the European Union which consists on reducing the public budget of education within the current Spanish context. The new Educational Law (LOMCE) has caused a generalized refusal leaded by students, teachers and social groups due to the negative effect over the autonomic competences and the teaching training. "A policy of rationalization must not be confused with a policy of non-discriminated reductions" (Gimeno and Rodríguez, 2013).

According to Bernal and Lorenzo (2013: 118-120), nowadays, the cuts which are being carried out by the government represent a new privatized model which leads to a general outdated segregation. This reductive process intends to convert education into a business in order to command the public schools under the management of some selected people. This new law is an undercover way to manage schools with almost no support from the government, making the public school loose quality little by little due to the lack of personal and material resources.

Therefore, the private and state subsidized school gets favoured while public schools are at risk of being a place where all the disadvantaged people are reunited. This makes schools which receive richer students grow in terms of resources whereas other schools will see decreased their staff.

The current crisis which affects Spain should not be an excuse for reducing the educational budget and other investments because of the low economical support that the government is facing and struggling. All these aspects should not be reduced 
because they help future generations to overcome past generations, and if we do not invest money and research on them, it will not be possible for them to ameliorate and lead this society to a better promising one.

According to Gimeno and Rodríguez (2013: 52), the cuts done by the government of Spain are a sample of proposals which attack the quality and the teachers' valuation. The salaries of teachers and their rights have been reduced substantially; the teachers' hours of work per week have been increased (from 18 hours until 21), as well as the pupils per classroom (from 25 students to more than 35), but there has been a reduction in terms of staff and material. Moreover, in many Communities of Spain, there have been reductions in the ongoing training of teachers.

One of the reasons of the educational reform, according to the Minister of Education, is to get closer to the Finnish Educational System by obtaining better results in international exams such as PISA. As Bolívar pointed out (2013: 1), instead of basing on outcomes from PISA, we should analyse how the Finnish System is preparing students so well. If we analyse LOMCE proposals, we can confirm that this new law promotes just the opposite of the Finnish System. What Bolívar is wondering is how to transform the current Educational System to another one which can better prepare the youngsters and at the same time guarantying a great education for everyone.

The following figure represents the differences between the Finnish and Spanish educational strategies:
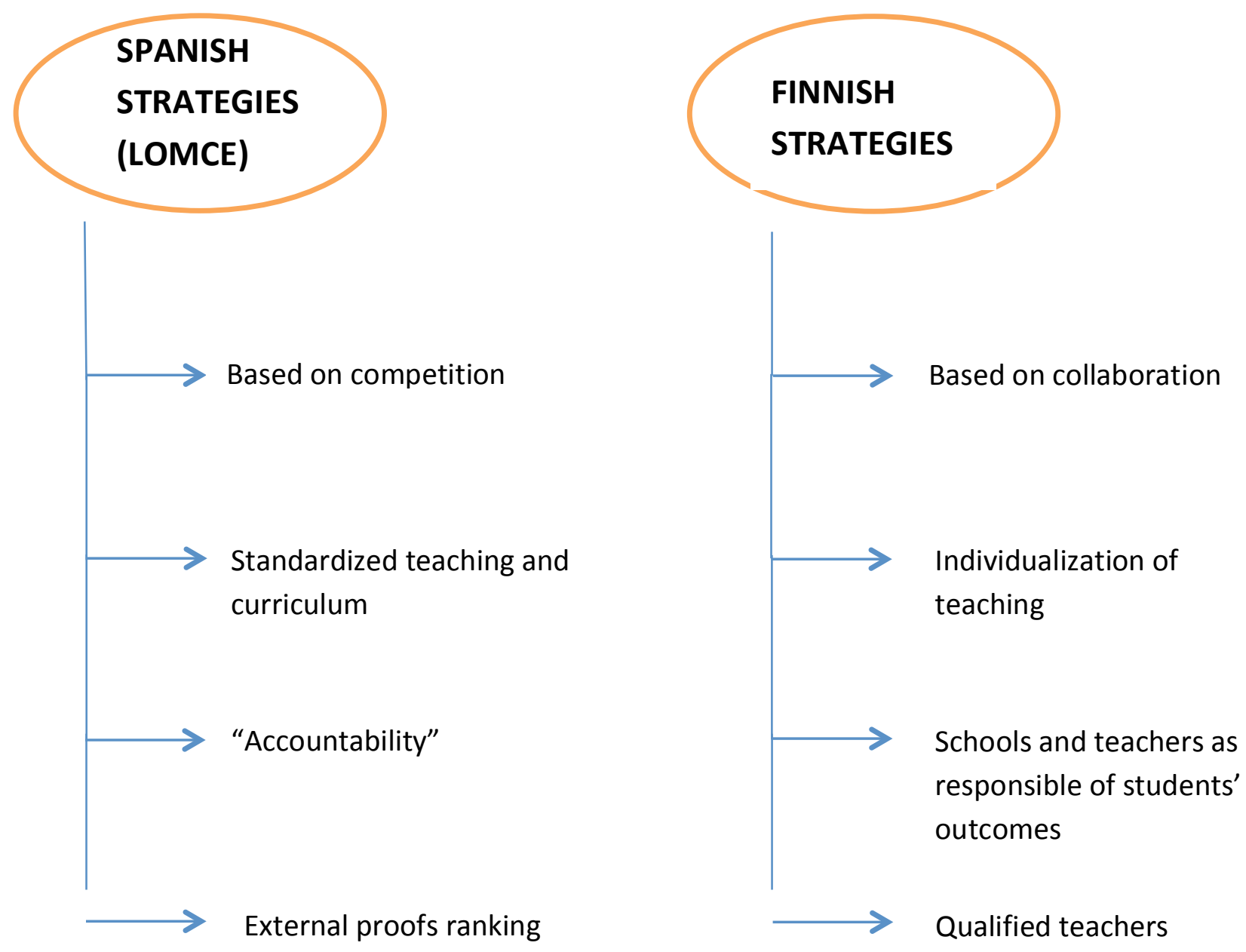
As a conclusion, Bolívar proposes a better teacher training in order to create qualified teachers and giving them the autonomy to decide how to teach, reducing at minimum the students' tests, which do not provide faithful outcomes, and giving more importance to the daily life progress at school, and not to the final.

If we focus on external exams, it could be used to value students or establish a ranking of schools, favouring the competition among them.

According to Gimeno and Rodríguez (2013: 46-49), the rankings established by the external tests of evaluation and the possibilities of specialization that each school offers will lead to a continuous competition among schools and a creation of schools from different categories (one school could be low quality whereas another school is considered as high quality).

While in public schools the number of modalities will be decreased, the private ones will keep all the possibilities in order to attract more students, so it makes the majority of students want to go to them in order to have more facilities to succeed.

Another important fact is the new autonomy that schools will have, leaded by the head teacher who will be able to choose the school staff. If we concentrate the power in only one person, we are centralizing the Educational System and we are removing the equal access for a vacancy for being a teacher. The School Council also loses the capacity for taking decisions and it turns into something exclusively informative, even the number of parents in the school council will decrease losing their participation in the process of the decision-making. The head teacher also has the power to choose the teachers of the school council, so they will act in favour of him in order to consolidate his mandate and not to be harmed from the decisions established by the school council.

The state subsidized schools, according to Bernal and Lorenzo (2013: 111), have a private control and management. The state pays directly the salaries to the teachers and gives a quantity to the school maintenance. Although the selection of teachers is theoretically public, these schools make a selection of their teachers without any strict control from the administration. By the way, the economical finance of these schools represents a way of explicit privatization and visible, where the public money is used to finance totally private schools. It has similar rules to the public schools (parents' choice of the school, management bodies...), but in the practice they are totally different. The management, the election of students, the election of teachers, the timetable of the school, etc., will be responsibility of only one person, who will have the power to make those decisions that he/she considers right.

Thereby, with the application of the law and the maintenance of the concerts with state subsidized schools, the government will try to centralise the power in some specific individuals who will lead the school under their interests.

The basic education is composed by Primary Education and Mandatory Secondary Education, the same way as in the previous law. The freedom of accessing this basic education is the same, being paid in private schools. On the other side, the scholarships have decreased in a considerable number, so students are in trouble in order to face the new prices and keep inside the system. This situation will provoke that families without enough resources will not be able to pay all the needs that education requires. 
Another main issue that the inequality can bring out, is the called digital divide, which consists of the unequal possibilities that students have to access to the different uses of ICT creating deficits in the students training. As digital media has had the massive implementation we all know, the person who does not know how to use these resources would have difficulty. We are not talking about having twenty computers per class, but about introducing students in the use of new technological tools, what is very important for creating future citizens and acting against the digital divide, which can create huge differences among people.

As a conclusion, according to Gimeno and Rodríguez (2013: 18-20), the objective of education acts just in the opposite way of what is proposed in the draft of this law (LOMCE). This objective is to understand the human development and social cohesion. The school is the main part of the citizenship structure and the government is doing all the necessary to destroy it, benefiting the private teaching and the one based on the indoctrination of students.

\section{REFERENCES}

Ley Orgánica 8/2013, de 9 de diciembre, para la mejora de la calidad educativa. Boletín Oficial del Estado, martes 10 de diciembre de 2013, núm. 295, pp. 97858-97921.

Gimeno \& Rodríguez, J. et al (2013). Por otra política educativa. Sevilla: Ediciones Morata.

Asociación “Soy Pública” (2013). Anteproyecto de la LOMCE analizado.

Bolívar A. y Uruñuela P. (2013). La LOMCE, la reforma que viene. Revista digital del Fórum Europeo de Administradores de la Educación de Aragón, 7, 9-30.

Bolívar, A. (2012). Hastiados de reformas educativas. Revista Escuela.

Bolívar, A. (2013). Volver a políticas educativas fracasadas. Revista Escuela, 277, 37.

Colectivo Lorenzo Luzuriaga. (2012). Documento sobre la LOMCE: Diez preguntas para el ministro Wert.

Bolívar, A. y San Fabián, J. L. (2013). La LOMCE, ¿una nueva ley para mejorar la calidad educativa? Artículo de actualidad, 1, 7-11.

Díez Gutiérrez, E. J. (2013). Entrevista a Enrique Javier Díez Gutiérrez sobre la LOMCE de la Wertgüenza (IV). Obtenido el 9/05/2013 de: http://lomceno.wordpress.com/2013/04/05/entrevista-a-enrique-javier-diezgutierrez-sobre-la-lomce-de-la-wertguenza-iv/ 